of this department, however, is assessing the commercial value of quality. What is most important, colour, taste or texture?

The biochemistry, histology and physiology department is investigating the biochemical changes immediately before and after slaughtering. Meat becomes more acid after slaughtering, because proteolytic cathepsins are liberated from lysosomes and the acidity affects the juiciness and tenderness of the meat. The institute would like to devise some method for accelerating the natural autolysis-hanging meat for two to three weeks is far too expensive, although it is done in the United States for the best steaks, and adding papain or ficin, which only begin to work in the oven, is unsatisfactory. Depending on the speed of cooking, the meat ends up either far too tender or no more tender than untreated meat. The institute is also studying the effect of tranquillizing animals before slaughter. It seems clear that if an animal gets excited before slaughter, the post mortem rise in acidity is either reduced or greatly increased and the quality of the meat suffers.

\section{Defence Research}

At its fourth public session on March 28, the Select Committee on Science and Technology spent two hours trying to find out what the Operation Analysis Committee of the Ministry of Defence does and what goes on at the Ministry's Defence Operation Analysis Establishment at Byfleet. It may not have succeeded, but at least it now has an invitation to a day out at Byfleet to see the war game facilities.

The committee was told by five taciturn representatives from the ministry that the Operation Analysis Committee investigates and supervises major longterm studies based on broad strategic assumptions. And the Byfleet establishment does for all three arms of the British forces what the Rand Corporation does under contract for the United States Air Force. But in the United States there are three independent organizations employed in strategic studies as well as the Rand Corporation and the Department of Defense, and Sir Ian Orr-Ewing expressed concern that in Britain all such work was kept within the ministry. The witnesses admitted that independent assessment was desirable and said that links with the Institute of Strategic Studies and the Institute of International Affairs have been increased in the past two to three years. By the initiative of the ministry, five university lectureships have also been established recently to support independent strategic studies. Dr David Owen, a Labour member of the Select Committee, agreed, however, that it will never really be possible to challenge defence and strategic decisions until expertise is developed outside the ministry, and that will not happen until the ministry contracts out work and also does away with the undue secrecy that shrouds its work.

The almost Byzantine structure of the Ministry of Defence prompted Mr Arthur Palmer, the chairman of the Select Committee, to ask why the ministry finds it necessary to have so many separate committees. He was told that defence is such a complex subject, with endless ramifications, that proliferation of committees is inevitable and even useful when it comes to making interdepartmental or inter-service decisions. Sir
Harry Legge-Bourke could not have been convinced. for he advocated an independent business management study of the structure of the whole ministry. As he said, there is a universal tendency for "old boy networks" to develop behind the facades of committees. and the secrecy that surrounds so much defence research can only exacerbate it.

The Navy, which keeps things to itself more and welcomes outsiders even less than the Army and Air Force, came in for particular scrutiny. Why did the Navy need to have its own researeh and development establishments rather than rely on industry" Were companies approved by the Navy still running a Buggin's turn system ? And did establishments such as Portland take contracts from private companies? Answering these questions, Mr Stuart Watson, who at the last meeting admitted to being pestered with ideas from the hovercraft industry, reminded the committee of the complexity of warships and maintained that the Navy is best at integrating all their components.

Mr Eric Lubbock, dissatisfied, called for a comparative survey of the age structure in naval research establishments and the Navy's civilian contractors. And as a parting shot, the chairman asked if the Navy had ever considered asking a contractor to build a complete warship.

\section{French Nuclear Energy Policy}

\section{from our Paris Correspondent}

THE long awaited report of the PEON Commission (Production of Energy of Nuclear Origin) over which M. Jean Couture, Secretary of State for Power, is presiding, will be published at last towards the end of April. Even now, certain of its main outlines are becoming known in Paris, and one can thus get a general idea of the policy which will very probably be drawn up for the coming years. A new report will, however, be issued in 1969, and this will constitute the definitive basis for the Sixth Plan (1970-1975).

Two aspects immediately come to one's attention. Firstly, the French effort will be more modest than was expected. Between the "high" theory which foresaw the building of generators capable of the production of 10,000 megawatts of nuclear electricity and the "low" theory which limits its horizon to 4,000 megawatts, it was the second which was chosen. This restrictive policy is based on the conviction that a much bigger programme would lead to premature investment, bearing in mind the fairly optimistic hopes of the breeder plants to which the Atomic Energy Commission is devoting two thirds of its official research budget. On the other hand, a much smaller programme would not be a sufficient incentive for the manufacturers of thermal generators: the competition for nuclear generators effectively forces the fuel producers to lower their prices to such an extent that it is to be hoped that we will soon reach a record low cost.

It seems that this fairly circumspect nuclear gamble meets the wishes of Electricité de France, which considers that in the present market conditions and for several years to come "classical" electricity will hold its own. EDF is not therefore intending to intensify its efforts, the more so because the series of incidents during the last few months in the French nuclear 